\title{
Yield and quality of melon under silicon doses and irrigation management in a greenhouse ${ }^{1}$
}

\author{
Cláudia Salim Lozano ${ }^{2}$, Roberto Rezende 2 , Tiago Luan Hachmann², \\ Fernando André Silva Santos ${ }^{2}$, Marcelo Zolin Lorenzoni ${ }^{2}$, Álvaro Henrique Cândido de Souza ${ }^{2}$
}

\section{ABSTRACT}

The netted melon requires special growing conditions, including a protected environment, an adequate staking system and proper water and nutrient management. This study aimed to assess the effect of irrigation levels and silicon doses on the yield and quality of Sunrise hybrid melons, in a greenhouse. A randomized block design was used, with a $5 \times 3$ factorial scheme and four replications. The first factor consisted of five silicon doses $\left(0 \mathrm{~kg} \mathrm{ha}^{-1}, 50 \mathrm{~kg} \mathrm{ha}^{-1}, 100 \mathrm{~kg} \mathrm{ha}^{-1}, 150 \mathrm{~kg} \mathrm{ha}^{-1}\right.$ and $\left.200 \mathrm{~kg} \mathrm{ha}^{-1}\right)$ and the second of three irrigation levels (40\%, $70 \%$ and $100 \%$ of the ETc). The results demonstrated that the applied irrigation levels and silicon doses have no influence on the yield traits of melon plants. The irrigation level corresponding to $100 \%$ of the ETc promotes higher values for soluble solids ( $\left.9.86^{\circ} \mathrm{Brix}\right)$ and maturation index (114.9) on fruits. The increase of silicon doses up to $200 \mathrm{~kg} \mathrm{ha}^{-1}$ also increases the maturation index in the treatment with the greatest irrigation level and reduces this index at the shallowest level applied.

KEYWORDS: Cucumis melo L.; water availability; fertirrigation.

\section{INTRODUCTION}

Melon (Cucumis melo L.) is highly appreciated worldwide and exports generate a significant income to Brazil (Ibraf 2016). The country is one of the largest producers in South America and ranks twelfth in global production (FAO 2014).

Most Brazilian melon production derives from outdoor crops. However, protected cropping has expanded significantly in recent years, especially for cultivars belonging to the cantaloupensis group (netted), prompting the need for technical information on the management and behavior of plants under this cultivation system (Queiroga et al. 2008).

\section{RESUMO}

Produtividade e qualidade de melão sob doses de silício e lâminas de irrigação em ambiente protegido

O melão rendilhado requer condições especiais de cultivo, como ambiente protegido, sistema de condução adequado e manejo de água e nutrientes. Objetivou-se avaliar o efeito de lâminas de irrigação e doses de silício na produtividade e qualidade de frutos do meloeiro híbrido Sunrise, em ambiente protegido. $\mathrm{O}$ delineamento experimental adotado foi em blocos ao acaso, em esquema fatorial $5 \times 3$, com quatro repetições. $\mathrm{O}$ primeiro fator consistiu de cinco doses de silício $\left(0 \mathrm{~kg} \mathrm{ha}^{-1}, 50 \mathrm{~kg} \mathrm{ha}^{-1}, 100 \mathrm{~kg} \mathrm{ha}^{-1}\right.$, $150 \mathrm{~kg} \mathrm{ha}^{-1}$ e $200 \mathrm{~kg} \mathrm{ha}^{-1}$ ) e o segundo de três lâminas de irrigação ( $40 \%, 70 \%$ e $100 \%$ da ETc). Os resultados demostraram que as lâminas de irrigação e as doses de silício aplicadas não influenciam nas características produtivas do meloeiro. A lâmina de irrigação referente a $100 \%$ da ETc promove maior valor de sólidos solúveis $\left(9,86^{\circ}\right.$ Brix) e índice de maturação $(114,9)$ dos frutos. O aumento das doses de silício até $200 \mathrm{~kg} \mathrm{ha}^{-1}$ resulta em aumento do índice de maturação no tratamento com maior lâmina de irrigação, bem como redução desse índice na menor lâmina aplicada.

PALAVRAS-CHAVE: Cucumis melo L.; disponibilidade hídrica; fertirrigação.

The netted melon is favored by consumers for its flavor and consistency. As such, it has a greater commercial value (Rizzo \& Braz 2004), requiring technologies that produce high fruit yield and quality. To that end, special growing conditions are needed, including a protected environment, a suitable staking system and a proper water and nutrient management (Maruyama et al. 2000).

Irrigation is an important aspect in the protected cropping of melon plants, whose shoots and roots are intolerant to high humidity (Sousa et al. 2011). Thus, applying suitable irrigation levels is very important, allowing high yields when the crop water demands are met. Dantas et al. (2011) found that a $28 \%$ decline in the irrigation level did not alter 
the melon production, and that soluble solid contents decreased at shallower levels. Sousa et al. (2016) observed a $62 \%$ rise in melon weight between the lowest and highest irrigation level.

Soil fertility is also a decisive production factor. Silicon ( $\mathrm{Si}$ ) has been widely studied in recent years (Silva et al. 2013, Miranda et al. 2018) and, despite not being considered essential to plants, applying this element has increased the resistance to biotic and abiotic stress and, in turn, improved the yield of different crops (Camargo 2016).

The literature contains multiple studies on the effect of Si in controlling melon plant diseases, such as bacterial fruit blotch (Preston 2013) and oidium (Dallagnol 2010). However, specific records on the performance of this crop fertilized with $\mathrm{Si}$, in relation to water consumption, are scarce.

Applying Si during the plant development may favor the production and post-harvest quality of fruits, exhibiting changes in soluble solids and titratable acidity content, as well as superior or inferior commercial quality (Silva et al. 2013).

Given the importance of the crop in the national economy, this study aimed at assessing the effect of Si and irrigation management on the yield and quality of the Sunrise hybrid melon, in a greenhouse.

\section{MATERIAL AND METHODS}

The experiment was conducted in a greenhouse of the Universidade Estadual de Maringá $\left(23^{\circ} 25^{\prime} \mathrm{S}\right.$, $51^{\circ} 57^{\prime} \mathrm{W}$ and $542 \mathrm{~m}$ above the sea level), in Maringá, Paraná state, Brazil, between 12 November 2015 and 19 February 2016. The structure (30 m x $6.9 \mathrm{~m} \mathrm{x}$ $3.5 \mathrm{~m}$ ) is built in the north-south direction, with an arched ceiling, coated with low-density polyethylene film $(150 \mu \mathrm{m}$ thick $)$ and containing a shading screen ( $30 \%)$ on the sides.

A randomized block design was used, with a $5 \times 3$ factorial scheme and four replications. The first factor consisted of five silicon doses $\left(0 \mathrm{~kg} \mathrm{ha}^{-1}, 50 \mathrm{~kg} \mathrm{ha}^{-1}, 100 \mathrm{~kg} \mathrm{ha}^{-1}, 150 \mathrm{~kg} \mathrm{ha}^{-1}\right.$ and $200 \mathrm{~kg} \mathrm{ha}^{-1}$ ) and the second of three irrigation managements (40\%, $70 \%$ and $100 \%$ of the crop evapotranspiration - ETc).

The soil in the experimental area is classified as a Distroferric Red Nitosol (Embrapa 2013), with a granulometry of $122.6 \mathrm{~g} \mathrm{~kg}^{-1}$ of sand, $120.6 \mathrm{~g} \mathrm{~kg}^{-1}$ of silt, $756.8 \mathrm{~g} \mathrm{~kg}^{-1}$ of clay, field capacity of $0.47 \mathrm{~cm}^{3} \mathrm{~cm}^{-3}$ and wilting point of $0.33 \mathrm{~cm}^{3} \mathrm{~cm}^{-3}$, as well as density of $1.34 \mathrm{Mg} \mathrm{m}^{-3}$. The soil chemical characterization obtained the following results: V\%: 85.35; cation exchange capacity (CEC): $17.34 \mathrm{cmol} \mathrm{dm}^{-3}$; water $\mathrm{pH}$ : 7.20; organic matter: $15.55 \mathrm{~g} \mathrm{dm}^{-3}$; P: $46.77 \mathrm{mg} \mathrm{dm}^{-3}$; $\mathrm{K}: 0.30 \mathrm{cmol}_{\mathrm{c}} \mathrm{dm}^{-3} ; \mathrm{Ca}^{2+}: 11.99 \mathrm{cmol}_{\mathrm{c}} \mathrm{dm}^{-3} ; \mathrm{Mg}^{2+}$ : $2.50 \mathrm{mg} \mathrm{dm}^{-3}$; $\mathrm{Cu}: 18.71 \mathrm{mg} \mathrm{dm}^{-3} ; \mathrm{Zn}: 20.34 \mathrm{mg} \mathrm{dm}^{-3}$; Mn: $94.61 \mathrm{mg} \mathrm{dm}^{-3}$; Fe: $68.97 \mathrm{mg} \mathrm{dm}^{-3}$; and B: $0.10 \mathrm{mg} \mathrm{dm}^{-3}$.

The experimental plots consisted of sixty $3-\mathrm{m}$ long and $0.5-\mathrm{m}$ wide rows. Seeds of the Sunrise hybrid melon were planted in 50-cell polyethylene trays containing a commercial substrate. Seedlings were transplanted when they displayed three to four leaves.

Each plot was composed of six plants, spaced $1.0 \mathrm{~m}$ between rows and $0.5 \mathrm{~m}$ between plants. Only the four central plants in each plot were considered. Plant staking was vertical and training used plastic ribbon on a single $1.90 \mathrm{~m}$ high stake, when the apical meristem was removed.

All the flowers between the fourth and sixth internodes were manually pollinated. Later, only one fruit per plant was kept.

Drip irrigation was used. This system consists of a $16 \mathrm{~mm}$ dripline on each bed, equipped with 12 pressure-compensating drippers, spaced $0.25 \mathrm{~m}$ apart, with a flow rate of $8 \mathrm{~L} \mathrm{~h}^{-1}$ and working pressure of 10 mca.

The irrigation levels applied during the growth cycle were $295 \mathrm{~mm}, 206 \mathrm{~mm}$ and $118 \mathrm{~mm}$, quantified by the ETc and measured using two constant water table lysimeters installed in the protected environment. The lysimeters were made of PVC boxes $(310 \mathrm{~L})$ connected to an auxiliary device consisting of a PVC tube $(200 \mathrm{~mm})$, water box float ball and known water supply. Two melon plants spaced $0.5 \mathrm{~m}$ apart were transplanted inside the lysimeters, in order to reproduce the bed conditions, such that the water removed by the plants was automatically replenished by capillarity. Water level readings and replacement in the supply tank occurred every morning at 7:00 a.m.

Fertirrigation with Si was applied four times during the growing season, the first at 30 days after transplanting and the remainder at 7-day intervals. The nutrient supply source contained $98 \%$ of $\mathrm{SiO}_{2}$. Silicon doses were dissolved in water to increase the application uniformity. The solution was applied using a portable pressurized system, consisting of an 
air compressor and a 5-L reservoir, equipped with an inlet through which the fertilizer solution was added and compressed air injected.

Harvesting was defined by a change in the epicarp color and formation of the abscission zone between the fruit and peduncle. After the harvest, fruit weight $(\mathrm{g})$ and longitudinal and transverse diameter were measured $(\mathrm{cm})$. Next, the fruits were cut in half to measure the pulp thickness $(\mathrm{cm})$, using a digital caliper. A representative sample (approximately $300 \mathrm{~g}$ ) of each fruit was also removed to determine the soluble solids content ( $\left.{ }^{\circ} \mathrm{Brix}\right)$ and $\mathrm{pH}$ by direct reading in the juice extract, with the help of a refractometer and digital $\mathrm{pH}$ meter, respectively, and titratable acidity (\% of citric acid) (IAL 2008).

The fruit shape index (longitudinal and transversal diameter ratio), maturity index (soluble solids and titrable acidity ratio) and estimated yield $\left(\mathrm{kg} \mathrm{m}^{-2}\right)$ were also calculated.

The data underwent variance analysis, comparison of means (Tukey test) at $5 \%$ significance and regression analysis of silicon doses, using the Sisvar 5.4 statistical software (Ferreira 2014).

\section{RESULTS AND DISCUSSION}

The analyzed variables (Table 1) inherent to the yield traits of the melon plant, including fruit weight, longitudinal and transverse diameter, fruit shape index, pulp thickness and estimated yield, showed no significant interaction with the Si dose and irrigation level, or statistical differences between the levels of each factor, according to the F-test $(\mathrm{p}>0.05)$.

The average fruit weight was $1.243 \mathrm{~kg}$, corroborating the value of $1.182 \mathrm{~kg}$ obtained by Dalastra et al. (2016), with the netted melon cultivar, in a protected environment. With respect to melon commercialization, larger fruits $(1.0-2.0 \mathrm{~kg})$ are more valued in the domestic market, in contrast to the export market, whose interest is for smaller specimens (0.5-1.0 kg) (Dusi 1992).

The average longitudinal and transverse diameters recorded were respectively $12.82 \mathrm{~cm}$ and $13.10 \mathrm{~cm}$, values above those reported by Rizzo \& Braz (2001), who assessed the characteristics of Sunrise melons grown in a greenhouse. These diameters are important indicators when selecting fresh fruits for sale, since they express size, while the ratio of these variables indicates the shape (Charlo et al. 2011).

The fruit shape index was 0.98 , classified as spherical (Lopes 1982). All shapes are accepted by the market, but spherical fruits are the most suitable for packaging and transport (Pádua 2001).

The average pulp thickness was $3.04 \mathrm{~cm}$, higher than the $1.83 \mathrm{~cm}$ reported by Cavalcanti et al. (2015) for the Mandacaru melon plant grown in a protected environment under different irrigation levels. The thicker the pulp the better, since it indicates a larger edible portion and heavier fruit weight, thereby enhancing its quality (Paduan et al. 2007).

The yield obtained here was $2.48 \mathrm{~kg} \mathrm{~m}^{-2}$. Vargas et al. (2008) assessed the performance of netted melon cultivars, as a function of cropping system, and obtained a yield of $2.44 \mathrm{~kg} \mathrm{~m}^{-2}$. Charlo et al. (2011) evaluated netted melon hybrids in two cropping systems, recording a yield of 3.82-4.45 $\mathrm{kg} \mathrm{m}^{-2}$.

The yield of these studies varied for the different melon cultivars. According to Dalastra et al. (2016), this may be related to the environment, genetic material used or crop management.

Average temperature and relative humidity data inside the protected environment, during the experimental period, are presented in Figure 1.

Table 1. Summary of variance analysis for fruit weight (FW), longitudinal (LD) and transverse (TD) diameter, fruit shape index (FSI), pulp thickness (PT) and estimated yield (EY) of Sunrise melon grown under silicon doses and irrigation levels.

\begin{tabular}{|c|c|c|c|c|c|c|c|}
\hline \multirow{3}{*}{ Source of variation } & \multirow{3}{*}{ DF } & \multicolumn{6}{|c|}{ p-value } \\
\hline & & FW & LD & TD & \multirow{2}{*}{ FSI } & PT & EY \\
\hline & & $\mathrm{g}$ & $\mathrm{cm}$ & $\mathrm{cm}$ & & $\mathrm{cm}$ & $\mathrm{kg} \mathrm{m}^{-2}$ \\
\hline Level (A) & 2 & $0.5708^{\mathrm{ns}}$ & $0.1703^{\text {ns }}$ & $0.3670^{\mathrm{ns}}$ & $0.3444^{\mathrm{ns}}$ & $0.8530^{\mathrm{ns}}$ & $0.5785^{\mathrm{ns}}$ \\
\hline Doses (B) & 4 & $0.8215^{\text {ns }}$ & $0.5879^{\mathrm{ns}}$ & $0.2542^{\mathrm{ns}}$ & $0.3591^{\mathrm{ns}}$ & $0.2529^{\mathrm{ns}}$ & $0.8221^{\mathrm{ns}}$ \\
\hline $\mathrm{A} * \mathrm{~B}$ & 8 & $0.3933^{\text {ns }}$ & $0.2748^{\mathrm{ns}}$ & $0.7820^{\mathrm{ns}}$ & $0.2924^{\mathrm{ns}}$ & $0.9243^{\mathrm{ns}}$ & $0.3974^{\mathrm{ns}}$ \\
\hline Block & 3 & $0.6907^{\mathrm{ns}}$ & $0.2973^{\mathrm{ns}}$ & $0.2294^{\mathrm{ns}}$ & $0.3224^{\mathrm{ns}}$ & $0.9192^{\mathrm{ns}}$ & $0.6919^{\text {ns }}$ \\
\hline $\mathrm{CV}(\%)$ & & 15.24 & 6.18 & 7.05 & 7.01 & 16.51 & 15.25 \\
\hline
\end{tabular}

${ }^{n s}$ not significant at $5 \%$ of probability; DF: degrees of freedom; CV: coefficient of variation. 
By staking only one fruit per plant (single drain), a good portion of the photoassimilates would be allocated to the formation of this fruit, preventing the competition between different fruits. This likely explains the fact that irrigation levels of $40 \%$ of the ETc exhibited yield traits similar to those of plants with irrigation levels of $70 \%$ and $100 \%$ of the ETc.

The absence of effect of Si doses on the yield traits of the melon plant in this study may be due to the possible interference of climatic conditions (Figure 1) on its absorption. According to Mitani \& Ma (2005), silicon can be absorbed without expending energy, accompanying the mass flow during the absorption of water by plants, i.e., the element moves according to the transpiration rate. The average relative humidity was high on most days after transplanting (Figure 1), what may have decreased the melon plant transpiration and, in turn, water absorption, in addition to reducing the silicon absorption.
The F-test results for $\mathrm{pH}$, soluble solids, titratable acidity and maturity index were significant $(p>0.05)$ for the irrigation level and the variables soluble solids and maturity index. The interaction between the factors was significant for soluble solids, titratable acidity and maturity index (Table 2).

The irrigation level of $100 \%$ of the ETc resulted in fruits with soluble solids content of $9.86{ }^{\circ}$ Brix, exceeding the levels of $70 \%$ and $40 \%$ of the ETc, in which fruits exhibited $8.53{ }^{\circ} \mathrm{Brix}$ and $8.72{ }^{\circ} \mathrm{Brix}$, respectively, according to the Tukey test.

Fruits from treatments that received levels of less than $100 \%$ of the ETc exhibited a lower soluble solids content. This may have been caused by the lower amount of water available to plants, which decreased photoassimilate productions (Figueiredo 2014) and affected the sugar content in the fruits.

These results differ from those reported by a number of authors (Koetz et al. 2006, Araujo et al. 2010), who observed that the soluble solids

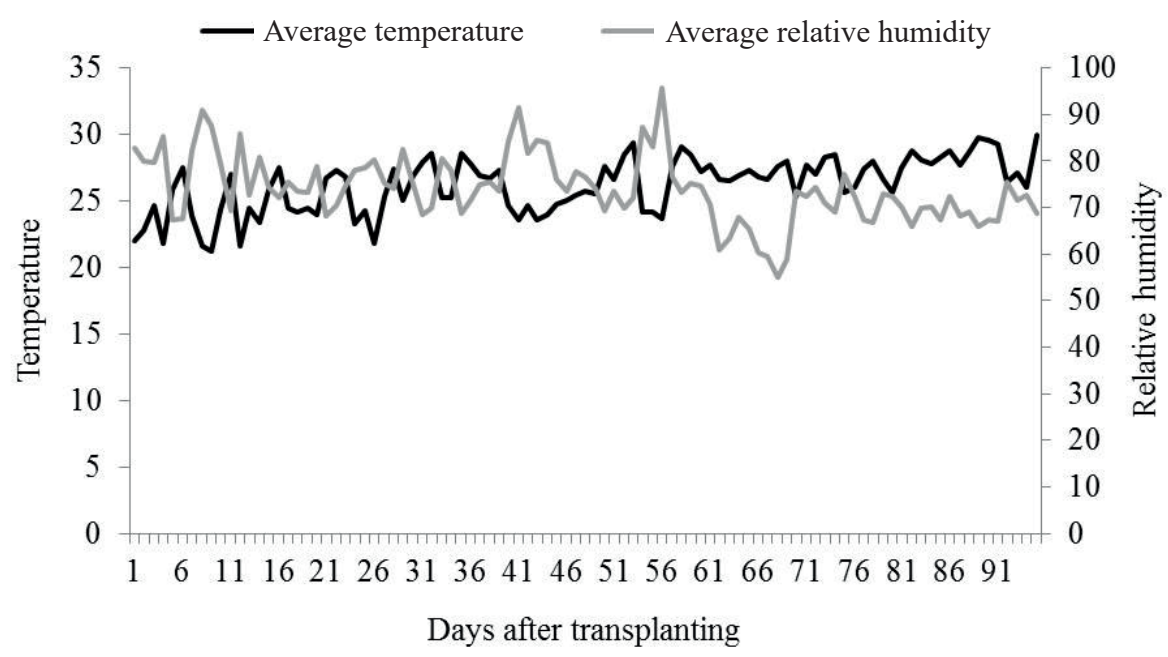

Figure 1. Average temperature $\left({ }^{\circ} \mathrm{C}\right)$ and relative humidity $(\%)$, during the Sunrise melon growth cycle $(11 / 17 / 2015$ to $02 / 19 / 2016)$.

Table 2. Summary of the variance analysis for the results of $\mathrm{pH}$, soluble solids, titratable acidity and maturity index of Sunrise melon grown under silicon doses and irrigation levels.

\begin{tabular}{|c|c|c|c|c|c|}
\hline \multirow[b]{2}{*}{ Source of variation } & \multirow[b]{2}{*}{ DF } & \multicolumn{4}{|c|}{ p-value } \\
\hline & & $\mathrm{pH}$ & $\begin{array}{l}\text { Soluble solids } \\
\text { ( }{ }^{\circ} \text { Brix) }\end{array}$ & $\begin{array}{l}\text { Titratable acidity } \\
\text { (\% citric acid })\end{array}$ & Maturity index \\
\hline Level (A) & 2 & $0.5908^{\mathrm{ns}}$ & $0.0008^{*}$ & $0.1391^{\mathrm{ns}}$ & $0.0163^{*}$ \\
\hline Doses (B) & 4 & $0.1518^{\text {ns }}$ & $0.6289^{\text {ns }}$ & $0.1173^{\mathrm{ns}}$ & $0.2813^{\text {ns }}$ \\
\hline $\mathrm{A} * \mathrm{~B}$ & 8 & $0.1581^{\mathrm{ns}}$ & $0.0115^{*}$ & $0.0012 *$ & $0.0051^{*}$ \\
\hline Block & 3 & $0.0490 *$ & $0.0604^{\mathrm{ns}}$ & $0.1006^{\mathrm{ns}}$ & $0.7170^{\mathrm{ns}}$ \\
\hline CV (\%) & & 3.46 & 12.20 & 13.40 & 17.72 \\
\hline
\end{tabular}


content was higher at shallower irrigation levels. In the present study, several cloudy days were recorded, providing less solar radiation for the crop. According to Wien (2002), factors that decrease the net photosynthesis rate, such as plant exposure to sunlight, have a significant effect on melon quality. In addition to sunlight, water availability also resulted in a lower soluble solids content at levels of $40 \%$ and $70 \%$, since these levels had less water supply, and stomatal opening and closing were limited. Under these conditions, photosynthesis was limited by two environmental factors, while, at the level of $100 \%$ of the ETc, it was affected only by the sunlight factor.

The analysis of the irrigation levels into each $\mathrm{Si}$ dose, in relation to the fruit soluble solids content, showed a significant effect $(p<0.05)$ of levels for the doses of $0 \mathrm{~kg} \mathrm{ha}^{-1}$ and $200 \mathrm{~kg} \mathrm{ha}^{-1}$. At the dose of $0 \mathrm{~kg} \mathrm{ha}^{-1}$, the treatment $\mathrm{L}_{100 \%}$ resulted in fruits with an average value of $11.20^{\circ} \mathrm{Brix}$, exceeding the treatments $\mathrm{L}_{70 \%}\left(7.42^{\circ} \mathrm{Brix}\right)$ and $\mathrm{L}_{40 \%}$ (8.65 ${ }^{\circ}$ Brix), which did not differ. For a dose of $200 \mathrm{~kg} \mathrm{ha}^{-1}$, the average soluble solids values were $9.97{ }^{\circ}$ Brix, $8.40^{\circ}$ Brix and $7.57^{\circ} \mathrm{Brix}$, respectively for the treatments $\mathrm{L}_{100 \%}, \mathrm{~L}_{70 \%}$ and $\mathrm{L}_{40 \%}$, demonstrating that the treatment $\mathrm{L}_{100 \%}$ exceeded the treatment $\mathrm{L}_{40 \%}$.

According to Silva et al. (2008), melon fruits should exhibit an average soluble solids content of more than $9{ }^{\circ}$ Brix, in order to meet international market standards. In the present study, only the treatment $\mathrm{L}_{100 \%}$ demonstrated a value within the recommended range.

Titratable acidity showed a significant difference only for the interaction between the factors (Table 2). With respect to the behavior of levels at each dose, a significant level effect was observed for $0 \mathrm{~kg} \mathrm{ha}^{-1}$ and $100 \mathrm{~kg} \mathrm{ha}^{-1}$. At the dose of $0 \mathrm{~kg} \mathrm{ha}^{-1}$, the treatment $\mathrm{L}_{100 \%}$ obtained an average value of $0.101 \%$ of citric acid, exceeding the treatments $\mathrm{L}_{70 \%}$ and $\mathrm{L}_{40 \%}$, which exhibited average values of $0.073 \%$ and $0.070 \%$ of citric acid, respectively. For the dose of $100 \mathrm{~kg} \mathrm{ha}^{-1}$, the treatment $\mathrm{L}_{40 \%}$ resulted in an average value of $0.113 \%$ of citric acid, surpassing the $\mathrm{L}_{100 \%}$ $(0.084 \%)$ and $\mathrm{L}_{70 \%}(0.081 \%)$ treatments.

The behavior of doses at each level demonstrated a significant effect only for the treatment $\mathrm{L}_{40 \%}$, fitting a quadratic model (Figure 2). Applying $\mathrm{Si}$ to the treatments with a $40 \%$ replenishment of the ETc promoted an increase in the titratable acidity of fruits up to a dose of $100 \mathrm{~kg} \mathrm{ha}^{-1}$, with a decline thereafter. Silva et al. (2013) assessed the influence of $\mathrm{Si}$ on the quality of strawberries and observed that the application increased the titratable acidity by $3-24 \%$, if compared to the controls.

The average values are within the range proposed by Mendlinger \& Pastenak (1992) for melons, whose citric acid percentage varies between $0.05 \%$ and $0.35 \%$.

With respect to the maturity index, a significant difference was observed, using the F-test, for the level factor and the interaction between level and dose (Table 2). The treatments $\mathrm{L}_{100 \%}, \mathrm{~L}_{70 \%}$ and $\mathrm{L}_{40 \%}$ demonstrated a maturity index of 114.9, 103.47 and 97.39 , respectively, in which the treatment $\mathrm{L}_{100 \%}$ exceeded and differed from the treatment $\mathrm{L}_{40 \%}$, i.e., plants that received an irrigation level of $100 \%$ of the ETc displayed fruits with high soluble solids content and low titratable acidity, producing a more pleasant flavor for commercialization.

The analysis of the levels for each dose, in relation to the maturity index, showed a significant effect of levels for $100 \mathrm{~kg} \mathrm{ha}^{-1}$ and $200 \mathrm{~kg} \mathrm{ha}^{-1}$ of Si. At $100 \mathrm{~kg} \mathrm{ha}^{-1}$, the maturity index values were 113.71 , 109.65 and 79.43 , respectively for the treatments $\mathrm{L}_{100 \%}, \mathrm{~L}_{70 \%}$ and $\mathrm{L}_{40 \%}$, with the treatment $\mathrm{L}_{100 \%}$ being superior to the $\mathrm{L}_{40 \%}$. For a dose of $200 \mathrm{~kg} \mathrm{ha}^{-1}$, the maturity index of the treatment $\mathrm{L}_{100 \%}$ was 143.68 , which exceeded the treatments $\mathrm{L}_{70 \%}$ and $\mathrm{L}_{40 \%}$, with average values of 97.78 and 88.35 , respectively.

The behavior of doses at each level revealed a significant effect, with a quadratic fit for $\mathrm{L}_{100 \%}$ and $\mathrm{L}_{40 \%}$ (Figures 3a and $3 \mathrm{~b}$ ).

According to Pinto et al. (2001), the maturity index is used to assess both the fruit maturation

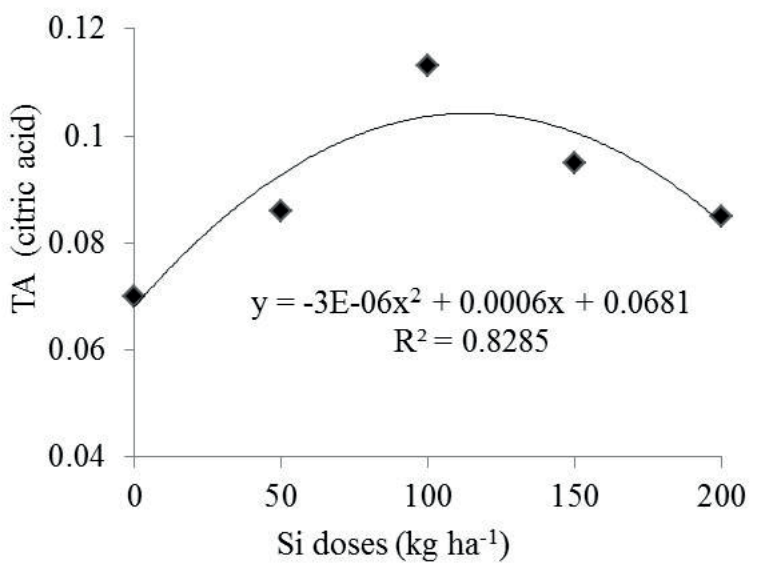

Figure 2. Titratable acidity (TA) of Sunrise melons, as a function of silicon doses and irrigation levels of $40 \%$ of the ETc. 


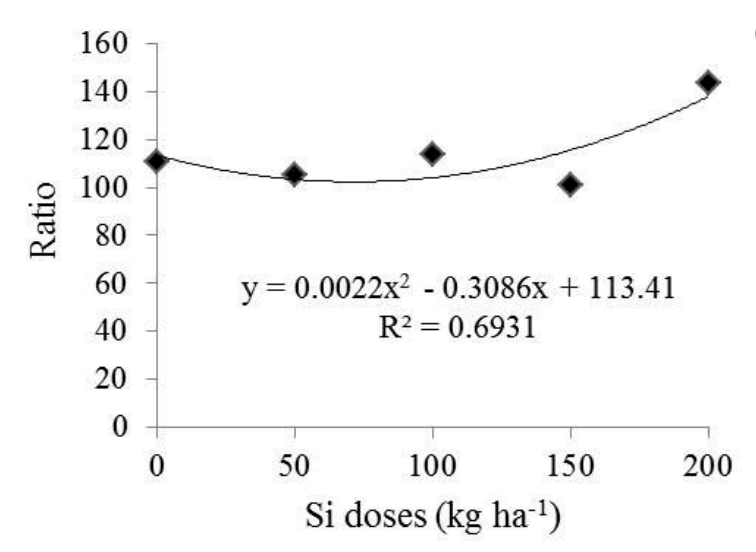

(a)

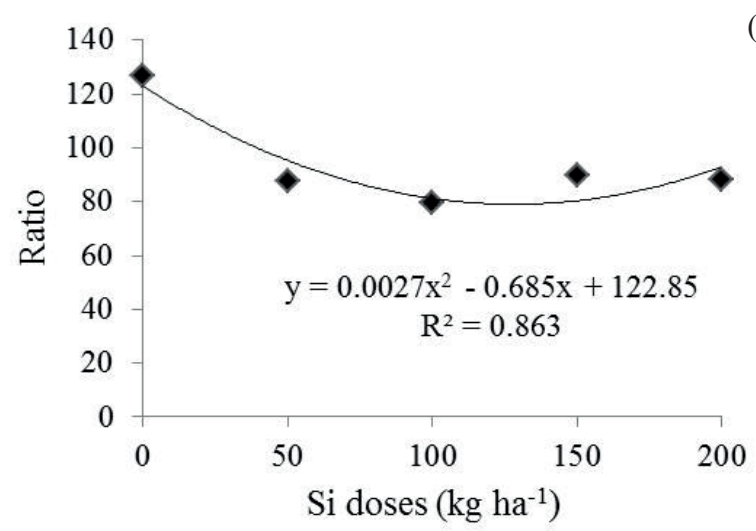

Figure 3. Maturity index of Sunrise melon fruits, as a function of silicon doses for the irrigation levels of $100 \%$ (a) and $40 \%$ (b) of the ETc.

state and palatability. The behavior of this variable shows that, for $100 \%$ of the ETc treatment, the dose of $200 \mathrm{~kg} \mathrm{ha}^{-1}$ promoted a higher maturity index. For the treatment that received the irrigation level of $40 \%$ of the ETc, the highest value was observed at the dose of $0 \mathrm{~kg} \mathrm{ha}^{-1}$, demonstrating that the $\mathrm{Si}$ lowered the maturity index in the soil with less water availability.

\section{CONCLUSIONS}

1. The irrigation levels and silicon doses applied do not affect the physical characteristics or estimated yield of melons;

2. The highest soluble solid and maturity index values are obtained under conditions without water stress (irrigation level of $100 \%$ of the ETc), providing a greater commercial value;

3. The silicon dose of $200 \mathrm{~kg} \mathrm{ha}^{-1}$ reduces the maturity index values under water stress, whereas this ratio increases in the absence of water stress.

\section{REFERENCES}

ARAUJO, W. F. et al. Manejo da irrigação do meloeiro com base na evaporação do tanque classe A. Horticultura Brasileira, v. 28, n. 4, p. 495-499, 2010.

CAMARGO, M. S. Efeito do silício na tolerância das plantas aos estresses bióticos e abióticos. Informações Agronômicas, n. 155, p. 1-8, 2016.

CAVALCANTI, N. M. S. et al. Aspectos agronômicos do meloeiro 'Mandacaru' cultivado em ambiente protegido sob irrigação. Irriga, v. 20, n. 2, p. 261-272, 2015.
CHARLO, H. C. O. et al. Híbridos experimentais de melão rendilhado cultivados em solo e substrato. Revista Brasileira de Fruticultura, v. 33, n. 1, p. 144-156, 2011.

DALASTRA, G. M. et al. Produção e qualidade de três tipos de melão, variando o número de frutos por planta. Revista Ceres, v. 63, n. 4, p. 523-531, 2016.

DALLAGNOL, L. J. Epidemiologia e bioquímica do controle do oídio do meloeiro por silício. 2010. $68 \mathrm{f}$. Tese (Doutorado em Fitopatologia) - Escola Superior de Agricultura Luiz de Queiroz, Piracicaba, 2010.

DANTAS, D. C. et al. Produção e qualidade do meloeiro cultivado com filmes plásticos em resposta à lâmina de irrigação. Revista Ciência Agronômica, v. 42, n. 3, p. 652661, 2011.

DUSI, A. N. Melão para exportação: aspectos técnicos da produção. Brasília, DF: Denacoop, 1992. (Publicações técnicas, 1).

EMPRESA BRASILEIRA DE PESQUISA AGROPECUÁRIA (Embrapa). Sistema brasileiro de classificação de solos. 3. ed. Rio de Janeiro: Embrapa Solos, 2013.

FERREIRA, D. F. Sisvar: a guide for its bootstrap procedures in multiple comparisons. Ciência e Agrotecnologia, v. 38, n. 2, p. 109-112, 2014.

FIGUEIREDO, R. C. Lâmina e frequência de irrigação na cultura do melão tutorado no vale do baixo São Francisco. 2014. 65 f. Dissertação (Mestrado em Engenharia Agrícola) - Universidade Federal do Vale do São Francisco, Juazeiro, 2014.

FOOD AND AGRICULTURE ORGANIZATION OF THE UNITED NATIONS (FAO). Statistical databases. 2014. Available at: $<$ http://www.fao.org $>$. Access on: 10 Nov. 2017. 
INSTITUTO ADOLFO LUTZ (IAL). Métodos físicoquímicos para análises de alimentos. São Paulo: Instituto Adolfo Lutz, 2008.

INSTITUTO BRASILEIRO DE FRUTAS (Ibraf). Estatistica. 2016. Available at: <http://www.ibraf.org.br/ estatisticas/Exporta\%C3\%A7\%C3\%A3o/Comparativo das_Exporta $\% \mathrm{C} 3 \% \mathrm{~A} 7 \% \mathrm{C} 3 \% \mathrm{~B} 5 \mathrm{es}$ B Brasileiras_de Frutas_frescas_2010-2009.pdf $>$. Access on: 15 Nov. $201 \overline{7}$.

KOETZ, M. et al. Produção do meloeiro em ambiente protegido irrigado com diferentes lâminas de água. Irriga, v. 11, n. 4, p. 500-506, 2006.

LOPES, J. F. Melhoramento genético (chuchu, melancia, melão e pepino). Informe Agropecuário, n. 85, p. 61-64, 1982.

MARUYAMA, W. I.; BRAZ, L. T.; CECÍLIO FILHO, A. B. Condução de melão rendilhado sob cultivo protegido. Horticultura Brasileira, v. 18, n. 3, p. 175-178, 2000.

MENDLINGER, S.; PASTENAK, D. Effect of time, salination of flowering, yield and quality factors in melon, Cucumis melo L. Journal of the American Society for Horticultural Science, v. 67, n. 4, p. 529-534, 1992.

MIRANDA, P. S. et al. Efeito do silício no cultivo e póscolheita do repolho. Revista Brasileira de Agroecologia, v. 13, n. 2, p. 30-35, 2018.

MITANI, N.; MA, J. F. Uptake system of silicon in different plant species. Journal of Experimental Botany, v. 56, n. 414, p. 1255-1261, 2005.

PÁDUA, J. G. Cultivo protegido de melão rendilhado, em duas épocas de plantio. 2001. $122 \mathrm{f}$. Tese (Doutorado em Agronomia) - Universidade Estadual Paulista, Jaboticabal, 2001.

PADUAN, M. T.; CAMPOS, R. P.; CLEMENTE, E. Qualidade dos frutos de tipos de melão, produzidos em ambiente protegido. Revista Brasileira de Fruticultura, v. 29, n. 3, p. 535-539, 2007.

PINTO, J. M. et al. Aplicação de $\mathrm{CO}_{2}$ via água de irrigação em relação à produtividade do meloeiro. Scientia Agricola, v. 58, n. 1, p. 33-38, 2001.
PRESTON, H. A. F. Potencial de fontes de silício no manejo da mancha aquosa em meloeiro. 2013. $142 \mathrm{f}$. Tese (Doutorado em Fitopatologia) - Universidade Federal Rural de Pernanbuco, Recife, 2013.

QUEIROGA, R. C. F. et al. Produtividade e qualidade do melão cantaloupe, cultivado em ambiente protegido, variando o número e a posição dos frutos na planta. Bragantia, v. 67, n. 4, p. 911-920, 2008.

RIZZO, A. A. D. N.; BRAZ, L. T. Características de cultivares de melão rendilhado cultivadas em casa de vegetação. Horticultura Brasileira, v. 19, n. 3, p. 237 240, 2001.

RIZZO, A. A. D. N.; BRAZ, L. T. Desempenho de linhagens de melão rendilhado em casa de vegetação. Horticultura Brasileira, v. 22, n. 4, p. 784-788, 2004.

SILVA, E. O.; ALVES, R. E.; SANTOS, E. C. Colheita e pós-colheita na produção integrada de melão. In: BRAGA SOBRINHO, R. et al. Produção integrada de melão. Fortaleza: Embrapa Agroindústria Tropical, 2008. p. 273-286.

SILVA, M. L. S. et al. Influência do silício na produção e na qualidade de frutos do morangueiro. Semina, v. 34, n. 6, p. 3411-3424, 2013.

SOUSA, A. E. C. et al. Influência de níveis de água e adubação potássica sobre parâmetros produtivos do meloeiro. Global Science and Technology, v. 9, n. 3, p. 172-179, 2016.

SOUSA, V. F. et al. Irrigação e fertirrigação na cultura do melão. In: SOUSA, V. F. et al. Irrigação e fertirrigação em fruteiras e hortaliças. Brasília, DF: Embrapa Informação Tecnológica, 2011. p. 659-687.

VARGAS, P. F. et al. Desempenho de cultivares de melão rendilhado em função do sistema de cultivo. Horticultura Brasileira, v. 26, n. 2, p. 197-201, 2008.

WIEN, H. C. The physiology of vegetable crops. 3. ed. New York: CAB International, 2002. 